\title{
The Role of Parents in Young People's Career Choices in Germany
}

\author{
Angela Ulrich, Andreas Frey, Jean-Jacques Ruppert \\ University of Applied Labour Studies, Mannheim, Germany \\ Email: andreas.frey@hdba.de
}

How to cite this paper: Ulrich, A., Frey, A., \& Ruppert, J.-J. (2018). The Role of Parents in Young People's Career Choices in Germany. Psychology, 9, 2194-2206. https://doi.org/10.4236/psych.2018.98125

Received: May 23, 2018

Accepted: August 20, 2018

Published: August 23, 2018

Copyright $\odot 2018$ by authors and Scientific Research Publishing Inc. This work is licensed under the Creative Commons Attribution International License (CC BY 4.0).

http://creativecommons.org/licenses/by/4.0/

\begin{abstract}
This article describes the relevant careers counselling services in Germany for school leavers, with a focus on the characteristic German "dual system" of vocational training. By the time they have reached the end of their school lives, most students have already made key decisions about their subsequent working lives and possible career paths. "Bad" decisions regarding training and higher education are often a factor in dropping out of vocational training or higher education (Frey, Ertelt, \& Ruppert, 2016), affecting approximately $25 \%$ of all dropouts from vocational training and approximately $30 \%$ of all dropouts from university (Frey, Balzer, \& Ruppert, 2014; Uhly, 2015). It is therefore imperative to investigate whether career counselling services address the right target group, when they are mainly targeting school leavers. According to data from the National Educational Panel Study (NEPS), from which cohort 4 (SC 4) was analyzed by descriptive data statistics, on various careers counselling offers, the influence of parents on young people's career choices is greater than that of teachers, of career counsellors or of occupation-specific information from the internet. Based on these findings, the authors recommend strengthening the parents' competences in order to enable them to better assist their children in making suitable career choices. Thus career counselling services could indirectly improve decision-making behaviours.
\end{abstract}

\section{Keywords}

Career Counselling, Sources of Information, Sources of Guidance, School-to-Work-Transition, Vocational Training, Parents

\section{Introduction}

In Germany, young people have the opportunity to plan their education and ca- 
reer paths independently and autonomously. 60.2\% (Federal Statistical Office, 2017) of young people leaving school in 2015 held a lower secondary or intermediate school-leaving certificate while 34.2\% (Federal Statistical Office, 2017) left school with a subject-specific or general certificate of aptitude for higher education. By the time they reach the end of their school lives, most students have already made key decisions about their subsequent working lives and possible career paths. As making these choices is just one of numerous development tasks that they face at this stage of life, young people are frequently confronted with excessive demands.

To enable them to make sound decisions in this regard, specific counselling services are available at every stage of life offering counselling on school and educational pathways, providing classroom-based career information and career-choice preparation, as well as the employment agencies delivering career counselling and career information in schools (Watts \& Sultana, 2004).

Schools offering general education (Allgemeinbildende Schulen) are legally required to provide counselling on school and educational pathways (Standing Conference of the Ministers of Education and Cultural Affairs, 2016), and this counselling focuses primarily on the choice of school type, educational stream and detailed subject combinations. Particular importance is attached to counselling during the transitions from one type of school to another and especially at the transition from primary education to lower secondary education. Young people also require counselling at the end of lower secondary education, as well as in upper secondary education, to help them identify their own interests, abilities and ideas and therefore to choose appropriate specific subjects or a specific type of secondary school to continue their studies (Ertelt \& Frey, 2013). Counselling on school and educational pathways also targets parents, who typically help their children in deciding on their educational pathway. For the young people, parents are one of many sources of guidance. As for the parents-the family's de facto in-house careers counsellors, they find themselves in a difficult role. If they know their children's strengths and weaknesses very well, they lack both a professional and objective perspective as well as expert knowledge of the labour market.

In schools offering general education, counselling is provided by guidance counsellors and social workers, as well as by career counsellors from the employment agencies collaborating with the schools. Classroom-based career information and career-choice preparation aim to prepare young people for the world of work by improving their career management skills, their ability to research and process information, as well as their decision-making strategies. These services are primarily implemented in the subjects of "Arbeitslehre" (introduction to the world of work), "Sozialkunde" (social studies) or "Wirtschaft und Recht" (business studies and law). In addition to classroom-based teaching, career information activities at schools usually also include work experience placements, visits to companies and a visit to the employment agency's Careers Information Centre (BIZ). The compulsory two- to three-week work experience 
placement in a company or an administration provides young people with first-hand experience of the conditions, opportunities and risks present in the world of work (Adler, 2013).

The career counselling and career information provided by the employment agencies in schools offering general education is actively supported by professional career counsellors (Rübner, 2009). Through their experience of the labour market and their direct contact with training companies and employers, career counsellors can more effectively help young people in selecting of a training occupation or training company. The employment agencies therefore offer a bespoke counselling service combining career information, individual counselling and training placement. Thus this service benefits not only the young people but also the employers, making it easier for them to find suitable trainees. The employment agencies provide individual career counselling sessions not only in their local offices but regularly also in schools offering general education. In addition, they give talks in the classroom, organise workshops and seminars, and supervise class groups at the Careers Information Centre (BIZ). The BIZ also hosts training fairs and seminars and talks on professions. Furthermore, the career counsellors assist the teachers in all matters relating to career information and education on career choices. These services are available in both lower and upper secondary education. The Federal Employment Agency publishes a wide variety of print and online media on the subjects of occupations, careers, and training and higher education opportunities, as well as self-assessment tests and information on the training and labour markets. These media are available to young people and their parents at the BIZ and online, as well as being distributed in schools (Federal Employment Agency, 2015).

For this article, data from the NEPS study (Blossfeld, Roßbach, \& von Maurice, 2011) were used. In a series of ongoing waves, the National Educational Panel Study (NEPS) has asked young people, parents and other actors about their educational behaviour. More than 60,000 people were sampled from 2009 to 2012 using a multi-cohort sequence design and following six starting cohorts in a longitudinal manner. This article describes cohort four, ninth graders, and was initiated in 2010. The representatively selected target individuals were regularly questioned and tested in different areas. The first survey for ninth graders was conducted in the autumn/winter of 2010. Parents, teachers and principals were regularly questioned up until 2014 as long as the target individuals were still enrolled in a general educating school institution. The respondents' further paths were individually followed after the school year of 2014/15, when the entire sample was completed. In a stratified cluster sampling about 14,540 students at regular schools all over Germany, 9180 parents of the participants, 1089 students at special schools, 1654 teachers and 495 heads of schools were questioned. Three different selection stages were used. Firstly, a random sampling of regular schools at lower secondary level. Five different types of schools existing in Germany were singled out and served as strata. Schools were drawn proportional to 
their number of classes: grammar schools, middle secondary schools, lower secondary schools, comprehensive schools, and schools offering all streams of secondary education bar the grammar school stream. An oversampling of schools in which students were likely to change into vocational training was implemented. Secondly, a random selection of grade nine classes at the selected schools took place. If the school had two grade nine classes, they were selected. And thirdly, all students from the selected classes were invited to participate in the study.

\section{The Transition from Lower to Upper Secondary Education}

The Federal Statistical Office (2017) indicates that in 2015, a total of 846,312 young people left schools offering general education in Germany - with or without a school-leaving qualification. Of those young people, 510,042 (60.2\%) (Federal Statistical Office, 2017) held a lower secondary or intermediate school-leaving certificate (Hauptschulabschluss or Realschulabschluss), and 288,835 (34.2\%, Federal Statistical Office, 2017) left school with a subject-specific or general certificate of aptitude for higher education (fachgebundene Hochschulreife or allgemeine Hochschulreife). A total of 47,435 young people (5.6\%, Federal Statistical Office, 2017) did however not obtain a school-leaving certificate.

These young people have reached the end of their compulsory education and in most cases, have made key decisions about their subsequent working life. The question is whether young people with a lower secondary or intermediate school-leaving certificate have now decided to switch to a general education or vocational upper secondary school, or to enter dual vocational training? Have young people with a subject-specific or a general certificate of aptitude for higher education decided to go to university, or have they switched to school-based or dual vocational training? And what opportunities were available to those young people without a school-leaving certificate? Before they could take such decisions, young people will have had to consider a whole series of options, while as a rule being supported, advised and influenced by their parents.

As in all transitions between different stages of life, this process presents opportunities and risks. Different aspects of stress and coping strategies can be dealt with, taking into account cognitive, affective and social facets (Ditton \& Krüsken, 2006). It is important to balance professional and personal aspirations against one's own capabilities, as well as taking into consideration the current circumstances on the labour market. Young people are confronted with a wealth of expectations from parents, friends and society they must evaluate and categorize. In this respect, the decision about their future education or career pathway is just one of a number of development tasks that they must overcome at this stage of their life (Flammer \& Alsaker, 2002). At the same time, the young people find themselves at that particular stage where, though no longer children but not yet adults yet either, they are acting increasingly autonomously. Their quest for autonomy therefore confronts their parents' legal right to make decisions on their children's behalf, as these are still legal minors. At this stage, parents are 
just one possible port of call for young people wishing to discuss their future career paths. Career counselling and information are on offer from numerous institutions and, above all, from the Federal Employment Agency. "Bad" decisions regarding training and higher education are often a factor in dropping out of vocational training contracts or higher education (Frey, Ertelt, \& Ruppert, 2016), affecting approximately $25 \%$ of all dropouts from vocational training and approximately $30 \%$ of all dropouts from university (Frey, Balzer, \& Ruppert, 2014; Uhly, 2015). At the same time, the trend in recent years has been quite heterogeneous. On one hand, the decisions reached at the end of lower secondary education are no longer as final as they once were, thanks to efforts to open up the education system. Now that school types and qualifications have been decoupled in various ways, it is possible to obtain qualifications regardless of the type of school you attend, as well as at a later point in time (Bellenberg \& Im Brahm, 2010). On the other hand, the vocational and training landscape and the range of university courses on offer are becoming increasingly nuanced and specialised to the extent that it is virtually impossible for young people to gain a clear overview on their own (Nota \& Rossier, 2015).

Career entry is now taking place at a later stage in life. According to a study by the Bertelsmann Stiftung (2007), a few decades ago young people were available to the labour market at the age of 18 . Today, the average age of those entering training is 19. Parents therefore find themselves in a "parental" role for a longer period of time (Baum \& Wagner, 2014) which further increases their influence on young people's career paths. Given the longer time that young people spend in education, parents also invest financially more in their children's training. From an emotional perspective, parents are mainly perceived as intensive counsellors and supporters in key educational and career-related matters (Hurrelmann, 2007). However, in the vast majority of cases, parents have no expert knowledge of occupational fields, and their knowledge of occupations may also be out of date, influenced by the media, or at odds with the opportunities that actually exist. Their view of their children is also influenced by their personal judgement and may not always be consistent with the assessment of a professional counsellor.

This article examines the degree of influence which parents have during this transition phase. To what extent do young people involve their parents and do parents involve themselves in the career guidance process? And to what extent do professional career counsellors manage to reach young people and compensate for any deficits in the counselling provided by the parents?

\section{Educational Decisions as a Process}

There are various approaches to explaining parents' influence on decisions made at the transition from lower secondary education, stemming both from sociology, whose approaches are transferred from phenomena on the macro level to the micro level, and from psychology, looking for explanations at the level of actors. 
The socialisation theory of Bourdieu (1983) explains educational decisions primarily by way of social capital effects, whereas Boudon (1974) talks about primary and secondary effects of the social background. As primary effects, Boudon (1974) refers to opportunities that open up as a result of educational achievements. Secondary effects are imparted by the social environment. The cost-benefit analysis of whether to make additional investments in a further educational pathway or to complete training reaches a different conclusion depending on the social background. Boudon's approach has its origins in the economic theory of subjective expected utility (Maaz, Hausen, McElvan, \& Baumert, 2006). Other rational choice models based on this theory tend to present the decision as an isolated occurrence within the transition phase. However, there are indications that decisions regarding educational pathways are actually negotiation processes on the actors' level, i.e. between the children and their parents or their wider environment, and therefore have the characteristics of a process (Ditton \& Krüsken, 2006). If this were to be confirmed, there should be a longer period in which the career-choice decision could be supported through counselling and information than if this decision were a one-off occurrence. However, this would mean that career counselling and career information could not only take place within a limited time frame, further strengthening the influence of the parental home on young people's career choices.

\section{Influence of Social Environment}

It is known from numerous earlier studies (e.g. Berger, Keim, \& Klärner, 2010) that the social environment and therefore the parents have an influence, perhaps even a decisive one, on their children's educational pathway and career. Parents are the most important people that their children turn to, specifically as advisers and role models (e.g. Kracke, Hany, Driesel-Lange, \& Schindler, 2013). In phases of transition from education or training phase into the next, the effects of social differences become particularly clear. This is true for decisions about the educational pathway between primary and secondary education (Ditton, 2013) but can also be applied to the educational decisions that come after lower secondary education. Young people do not take the decisions about their future educational pathways on their own. On school-leavers with a subject-specific or a general certificate of aptitude for higher education, a 2010 study of the university information system (Heine, Willich, \& Schneider, 2010) observed that only 7\% of this group did not have any problems with their decision about their post-school pathway. Here, key factors include the degree of embedding in a social framework and the support from the parental home. Coleman refers already in 1966 to the importance of the extracurricular environment to successful learning, citing above all parents but also the young people's friends as important actors. This influence appeared to depend strongly on social status, and has been confirmed in further studies (e.g. Jencks, Smith, Acland, Bane, Cohen, Gintis, Heyns, \& Michelson, 1973). As young people get older and more independent, their par- 
ents' influence on their decisions declines (e.g. Meulemann, 1985). Nevertheless, as shown by the results of a large-scale study in Switzerland, parents' educational aspirations are more reliable than other predictors such as grades, of educational pathways over the course of two educational transitions (Neuenschwander \& Malti, 2009). At the same time, less-educated parents aspire from the outset to lower qualifications for their children than parents with a higher level of education.

\section{Sources of Information for Choosing a Career}

The NEPS survey can provide details on how parents support their children and on how students ask for their assistance as well as what sources of information students are using in their career orientation.

In the first survey, i.e. before completing lower secondary education and entering vocational training or continuing secondary school, these students were asked how relevant various sources of information were to them (Figure 1). Questions were asked about vocational preparation by the school, careers counselling at the employment agency, and the information provided by the media, by family, by friends and acquaintances, by individual teachers, as well as about work experience placements and jobs.

The results in Figure 1 show that the young people in Grade 9 who were surveyed for the NEPS viewed their parents as the most important source of information. The next most important source was considered to be various opportunities to try out an occupation, such as a work experience placement or a vocational preparation. The "farther" the individuals providing advice were from the family or everyday environment, the less important the respondents perceived their information to be. The media came in last place which was surprising given the universally high level of media affinity that young people have nowadays.

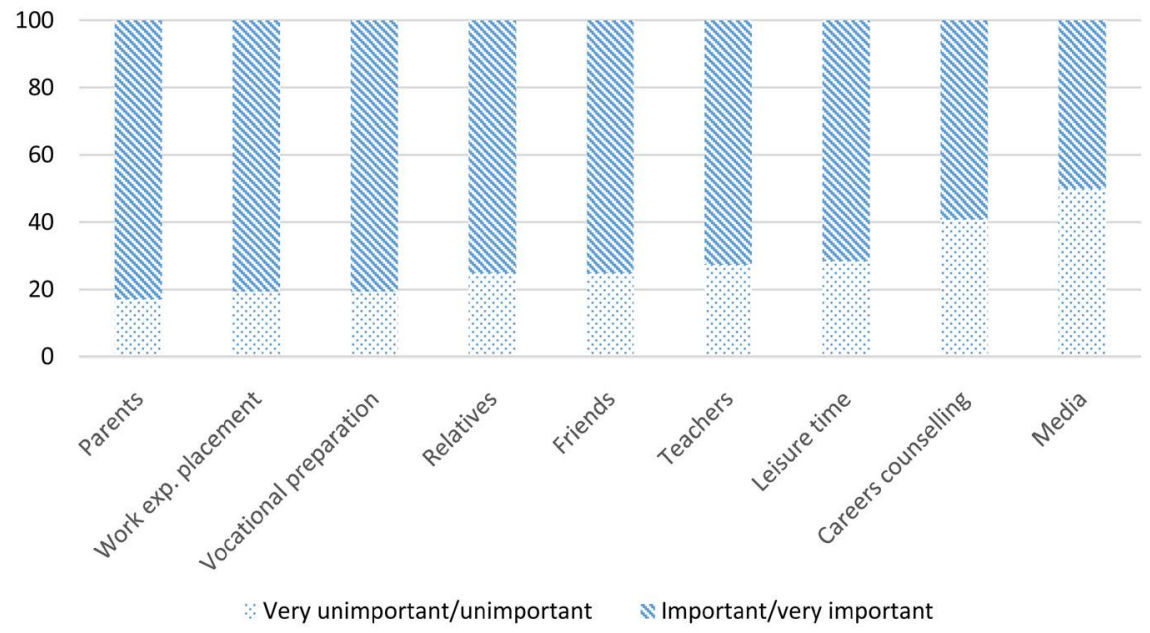

Figure 1. Assessment of relevance of various sources of information, in \%. Question: "How important/unimportant are the following sources of information for your job choice?" Source: NEPS Wave 1, SC 4, Version 7.0.0 Grade 9. 
When asked how helpful the various sources of information were in their actual search for a training position (Figure 2), the young people answered that above all their work experience placement was either rather or very helpful for them, followed by their parents' assessment.

The NEPS also asked the young people's parents about the extent to which they supported their children in the process of choosing a career and applying for training positions (Figure 3). The overwhelming majority of parents (95\%) talked to their children about what they wanted for their future. Practical support was usually provided prior to the application. Parents obtained information about training positions (68\%) or regularly checked the student's homework (43.5\%) even though they had almost reached the end of their time at school.

Summer 2011
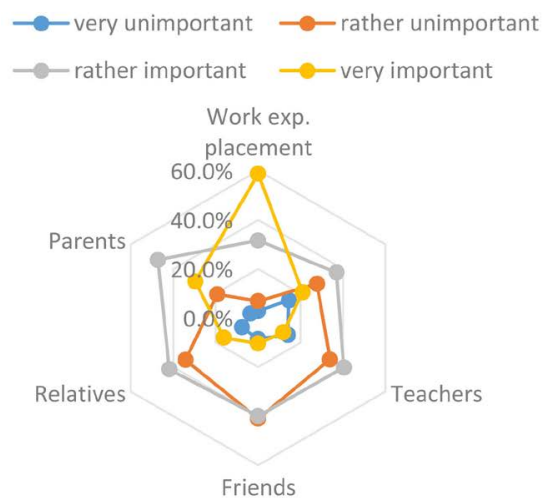

$2011 / 2012$

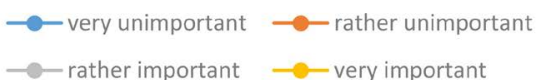

.

placement

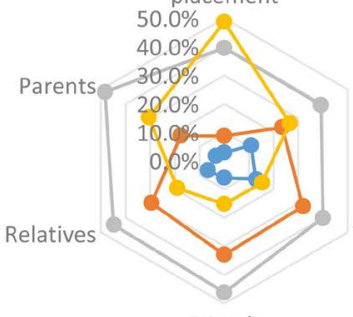

Careers

counsellors/s

ocialed workers

Friends

Figure 2. "When looking for an open vocational training position, how important are the following sources of information to you?" Respondents from Wave: Summer 2011 and 2011/2012. Source: NEPS Wave 1, SC 4, Version 7.0.0 Grade 9.

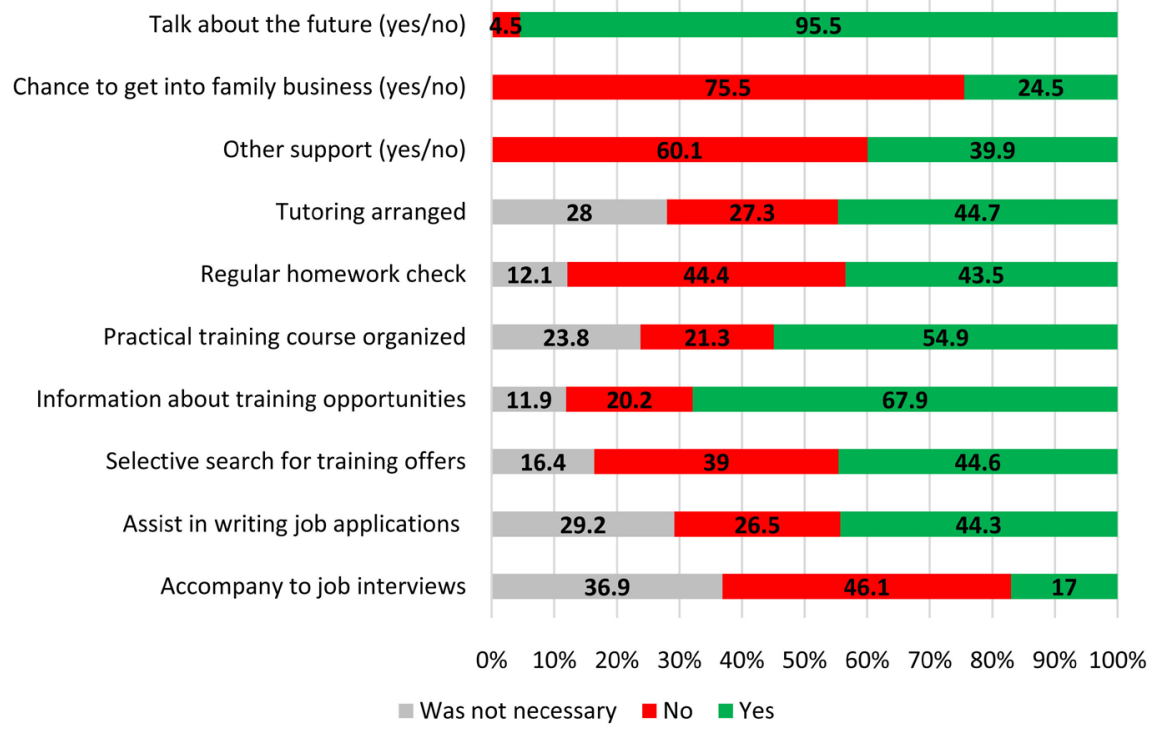

Figure 3. Support according to parents (Autumn 2010), in \%. Source: NEPS Wave 1, SC 4, Version 7.0.0 Grade 9. 
Only $17 \%$ of parents accompanied their child to the interview for a training position, with $37 \%$ deeming this unnecessary.

The results shown in Figure 3 reflect the view that parents provided their children with extensive support with approximately $68 \%$ of parents searching for information on training opportunities, just under 55\% organising a work experience placement, and approximately $45 \%$ selectively looking into training programmes, organising tutoring (45\%) or helping with writing applications (44\%). The parents therefore played an extensive and central role in the career orientation process for which they require specific knowledge.

\section{Career Counselling by Parents as a Demanding Process}

As a family's in-house career counsellors, parents find themselves in a difficult role. On the one hand, most parents have supported their children from birth and know their strengths and weaknesses inside out. On the other hand, they lack a professional, objective view of these young people. They also lack expert knowledge in terms of the labour and vocational training markets and their developments. The expression "the parents" is also confusing as this ostensibly homogeneous group does not exist. People from all parts and levels of society have children, and so the parental composition is also extremely heterogeneous. Not all parents have the personal prerequisites to assist their children in a capacity of advisers. Sometimes, parental advice also reaches a conclusion that is not shared by professionals and does not always help the young persons to position themselves successfully on the labour market. Parents with a low level of school education have been found to have knowledge gaps as regards not only the opportunities but also possible courses of action that certain school-leaving certificates open up (Deppe, 2013). It also is still more difficult for young people from non-academic families to get into sixth form and to successfully complete it (Klomfaß, Stübig, \& Fabel-Lamla, 2013).

Parents are well aware of their role during the process of choosing a career, with $92 \%$ of parents and guardians stating in a study by Voigt (2010) that the subject of career choice is important to them. A further $87 \%$ of parents also see themselves as being responsible for supporting their children actively in this transition.

According to Ditton (2014) the child's or young person's social positioning is also a significant factor in their career choice. When it comes to the parents' educational aspirations, there is a difference as a function of the family living in a rural or in an urban environment, in a prosperous or in a deprived neighbourhood, or in Eastern or in Western Germany.

\section{Findings and Discussion}

According to our data the influence of parents on young people's career choices is greater than that of vocational teachers or career counsellors as well as that of occupation-specific information available on the Internet. The finding that information from the Internet is not as seminal as anticipated is surprising con- 
sidering the influence the Internet exerts on students in other domains. Given that the social group a person belongs to can exert an institutional influence not only on the educational decisions actually implemented but even on the parents' educational aspirations, there is plenty of evidence to suggest that this influence also applies to the choice of vocational training. It might therefore be extremely helpful to define parents as a new regular target group for career counselling. Our results show that careers counselling services are rather unimportant for students' decision making. But the expertise and the in-depth knowledge careers counselling services provide can empower parents. Coordinated services for parents could create the circumstances for balancing out parents' different starting conditions. To this end there is a great need for individual information and counselling services for parents so that they are in a better position to provide informed advice to their children. At the same time various mitigating circumstances such as a migrant or a single-parent family background must be taken into account. In particular young people from homes with a low level of school education should benefit from professional information at an early stage in order to clarify possible courses of action in terms of individual school-leaving certificates and opportunities for training and higher education (Deppe, 2013).

As the overall family atmosphere and interactions within the family have a considerable influence on the form and the quality of advice that parents provide on career choices, it is sensible to explore the forms of interaction within the family and to include positive examples in the counselling given to parents (Schmitt, 2009).

When it comes to real job-seeking for a vocational education position, the influence of and the trust in professional services increases, but the impact parents have remains high (Figure 2). As the career entry date draws nearer the other information sources gain in influence (Figure 2). One reason could be that students use a broad range of possibilities to seek a position. Furthermore, the importance of contacts made in their practical work experience increases. As with their parents, students have a combination of a personal relationship with accredited professionals and possess an archetype for a specific career. This indeed seems to be very helpful for students' occupational orientation.

\section{Conclusion}

As shown in this analysis, there is a wide range of information and counselling services for students in Germany when it comes to career decisions. Professional counsellors and information providers are mainly targeting students. Students however perceive their parents as being more helpful. Given the high number of dropouts from vocational training, the challenge is to find ways to increase the existing range of services for career guidance in order to prevent "bad" decisions. Finally, the idea that counselling services should target parents with a view of strengthening their role in the decision making process of their children looks like a promising avenue that should be further investigated. 
Working continuously with parents from an early stage could enable them to better manage the influential role they have in their children's career planning and assist them in a responsible way. It might also help to give children from low-education households increased opportunities to take up training or studies corresponding to their abilities by communicating relevant information on careers and support services in good time. This would however require the creation of a systematic structure for what must be called parental outreach work.

\section{Notes}

This paper uses data from the National Educational Panel Study (NEPS): Starting Cohort Grade 9, DOI: 10.5157/NEPS:SC4:7.0.0. From 2008 to 2013, NEPS data was collected as part of the Framework Program for the Promotion of Empirical Educational Research funded by the German Federal Ministry of Education and Research (BMBF). As of 2014, NEPS is carried out by the Leibniz Institute for Educational Trajectories (LIfBi) at the University of Bamberg in cooperation with a nationwide network.

\section{Conflicts of Interest}

The authors declare no conflicts of interest regarding the publication of this paper.

\section{References}

Adler, S. (2013). Professionalisation of Career Guidance-A New Challenge-Part 1. Economy and Profession. Journal for Vocational Education, 6, 65.

Baum, S., \& Wagner, B. (2014). Cooperation with Parents in School-Work-Transition. In N. Pötter (Ed.), Educational Social Work in School-Work Transition. Contributions to Social Work in Schools (pp. 187-207). Wiesbaden: Springer Fachmedien. https://doi.org/10.1007/978-3-531-19060-0_11

Bellenberg, G., \& Im Brahm, G. (2010). Reduction of Selection and Transition Barriers. In G. Quenzel, \& K. Hurrelmann, (Eds.), Educational Losers (pp. 517-535). Wiesbaden: VS Publisher for Social Sciences. https://doi.org/10.1007/978-3-531-92576-9_24

Berger, P. A., Keim, S., \& Klärner, A. (2010). Educationally Disadvantaged-A New Marginal Group? In G. Quenzel, \& K. Hurrelmann (Eds.), Educational Losers (pp. 37-51). Wiesbaden: VS Publisher for Social Sciences. https://doi.org/10.1007/978-3-531-92576-9_2

Bertelsmann Stiftung. (2007). Guide for Local Transition Management. From the Problem Diagnosis to the Practical Implementation.

Blossfeld, H.-P., Roßbach, H.-G., \& von Maurice, J. (Eds.) (2011). Education as a Lifelong Process-The German National Educational Panel Study (NEPS). Journal for Educational Sciences, 14, 19-34. https://doi.org/10.1007/s11618-011-0179-2

Boudon, R. (1974). Education, Opportunity, and Social Inequality. Changing Prospects in Western Society. New York: Wiley.

Bourdieu, P. (1983). Economical, Cultural and Social Capital. In R. Kreckel (Ed.), Social Inequalities (pp. 183-198). Göttingen: Schwartz.

Deppe, U. (2013). Younger Adolescents between Family, Peers and School. Of the Origin 
of Educational Inequality at Out-of-School Education Places.

Ditton H., \& Krüsken, J. (2006). The Transition from the Elementary School to the Secondary School I. Journal for Educational Sciences, 9, 348-372. https://doi.org/10.1007/s11618-006-0055-7

Ditton, H. (2013). Who Goes to the Secondary Modern School? Primary and Secondary Effects of the Social Origin at the Transition after the Elementary School. Journal for Educational Sciences, 16, 731-749. https://doi.org/10.1007/s11618-013-0440-y

Ditton, H. (2014). Bildung und Region (NEPS Working Paper No. 44). Bamberg: Leibniz Institut für Bildungsverläufe, Nationales Bildungspanel.

Ertelt, B.-J., \& Frey, A. (2013). Diagnosis of Interests and Motivation in Vocational Contexts. In A. Frey, U. Lissmann, \& B. Schwarz (Eds.), Manual for Vocational Pedagogical Diagnostics (249-272). Weinheim: Beltz.

Federal Employment Agency (2015). Career Guidance, Orientation and Choice in Education. Nuremberg: Federal Employment Agency.

Federal Statistical Office (2017). Graduates and Persons Leaving by Type of School Leaving Certificate.

Flammer, A., \& Alsaker, F. D. (2002). Developmental Psychology of the Adolescence. Bern: Huber.

Frey, A., Balzer, L., \& Ruppert, J. J. (2014). Transferable Competences of Young People with a High Dropout Risk in Vocational Training in Germany. International Journal for Educational and Vocational Guidance, 14, 119-134. https://doi.org/10.1007/s10775-013-9257-8

Frey, A., Ertelt, B.-J., \& Ruppert, J.-J. (2016). Abbrüche in der beruflichen Ausbildung: Gründe, Folgen und Möglichkeiten der Prävention. In A. Bienfait, \& A. Frey (Eds.), Drop out from Vocational Education Training. Reasons, Consequences and Possibilities for Prevention. Empirical Pedagogics, 30, 3, 4, Special Issue. Landau: Publisher Empirical Pedagogics.

Heine, C., Willich, J., \& Schneider, H. (2010). Information Behaviour and Decision Making in Study and Career Orientation. 2008 Students, Half a Year before the University Entrance Qualification. Information System on Higher Education (HIS).

Hurrelmann, K. (2007). Adolescence, a Phase-of-Life. An Introduction into the Socio-Scientific Youth Research (9th ed.). Weinheim: Juventa.

Jencks, C., Smith, M., Acland, H., Bane, M. J., Cohen, D., Gintis, H., Heyns, B., \& Michelson, S. (1973). Chancengleichheit. Hamburg: Rowohlt.

Klomfaß, S., Stübig, F., \& Fabel-Lamla, M. (2013). The Transition from Lower Secondary School to the Grammar-School Senior Classes under the Terms of Schooltime Reduction. In D. Bosse, F. Eberle, \& B. Schneider-Taylor (Eds.), Standardisation in Upper Secondary Education (pp. 147-160). Wiesbaden: Springer. https://doi.org/10.1007/978-3-658-00658-7_9

Kracke, B., Hany, E., Driesel-Lange, K., \& Schindler, N. (2013). Career Decision of Adolescent with University Entrance Qualification. In T. Brüggemann, \& S. Rahn (Eds.), Career Counselling. A Text and a Workbook. Münster: Waxmann.

Maaz, K., Hausen, C., McElvany, N., \& Baumert, J. (2006). Keyword: Transitions in Educational System. Theoretical Concepts and Its Application in Empirical Research at the Transition to the Lower Secondary School. Journal for Educational Sciences, 9, 299-327. https://doi.org/10.1007/s11618-006-0053-9

Meulemann, H. (1985). Education and Plans for the Future. The Relationships between Parental Home and School. 
Neuenschwander, M. P., \& Malti, T. (2009). Selection Processes at the Transition into Lower and Upper Secondary School. Journal for Educational Sciences, 12, 216-232. https://doi.org/10.1007/s11618-2009-0074-2

Nota, L., \& Rossier, J. (2015). Handbook of Life Design: From Practice to Theory and from Theory to Practice. Boston: Hogrefe.

Rübner, M. (2009). Further Strengthening of Career Guidance. Objectives and Perspectives of the Federal Employment Agency. Vocational Training in Science and Practice, 4, 14-18.

Schmitt, M. (2009). Relationships within a Family and Successful Education. Journal for Educational Sciences, 12, 715-732. https://doi.org/10.1007/s11618-009-0095-x

Standing Conference of the Ministers of Education and Cultural Affairs (2016). The Education System in the Federal Republic of Germany 2013/2014. A Description of the Responsibilities, Structures and Developments in Education Policy for the Exchange of Information in Europe.

Uhly, A. (2015). Early Termination of Contracts and Vocational Training History in the Dual System. Current State of Research, Available Data Records and Analyses Based on the Statistics for Vocational Training. http://www.bibb.de/veroeffentlichungen

Voigt, J. (2010). Parents and Career Orientation.

Watts, A. G., \& Sultana, R. G. (2004). Career Guidance Policies in 37 Countries: Contrasts and Common Themes. International Journal for Educational and Vocational Guidance, 4, 105-122. https://doi.org/10.1007/s10775-005-1025-y 